\title{
Perspectives for Biochar as a vehicle for inoculation of phosphate solubilizing
}

\section{bacteria: a review}

\author{
Perspectivas do Biochar como veícullo para inoculação de bactérias solubilizadoras de fosfato: uma \\ revisão
}

Perspectivas del Biochar como vehículo para la inoculación de bacterias solubilizantes de fosfato: una revisión

\begin{abstract}
Phosphorus (P) plays a vital role in many aspects of plant growth and development. The low amount of available P in agricultural soils reduces crop productivity and phosphate fertilizers are often applied. However, due to the high affinity of $\mathrm{P}$ for the soil constituents, the availability of this element becomes limited to plants. Thus, alternative, ecological, and low-cost techniques have been studied to improve $\mathrm{P}$ acquisition by crops. Microorganisms able to solubilize $\mathrm{P}$, mainly phosphate-solubilizing bacteria (PSB) have stood out, since they offer an approach to overcome P scarcity by their introduction in agricultural systems via inoculants. In this paper, we showed the potential of P-solubilizing microorganisms and their mechanisms of action, the potential of different inoculation vehicles, also highlighting the biochar as a viable biological product for production of inoculants. The combined effects of these factors (PSB and biochar) add several benefits to the soil-plant system. Results from this review demonstrate that biochar amendments have great potential as a vehicle for inoculation of PSB. However, studies of biochar combined with PSB is still incipient. Future research should focus efforts on exploring highly efficient strains, optimizing conditions, and assessing several sources of waste for production of biochar and their efficiency in field experiments.
\end{abstract}

Keywords: Available phosphorus; Solubilizing microorganisms; Inoculants. 


\section{Resumo}

O fósforo (P) desempenha um papel vital em muitos aspectos do crescimento e desenvolvimento das plantas. A baixa quantidade de $\mathrm{P}$ disponível em solos agrícolas reduz a produtividade da cultura e fertilizantes fosfatados são frequentemente aplicados. Porém, devido à alta afinidade do $\mathrm{P}$ pelos constituintes do solo, a disponibilidade desse elemento torna-se limitada às plantas. Assim, técnicas alternativas, ecológicas e de baixo custo tem sido estudadas para melhorar a aquisição de $\mathrm{P}$ pelas culturas. Microrganismos capazes de solubilizar P, principalmente bactérias solubilizadoras de fosfato (BSF), têm se destacado por oferecer uma abordagem para superar a escassez de $\mathrm{P}$ por meio de sua introdução em sistemas agrícolas via inoculantes. Neste trabalho, mostramos o potencial de microrganismos solubilizadores de $\mathrm{P}$ e seus mecanismos de ação, o potencial de diferentes veículos de inoculação, destacando também o biochar como um produto biológico viável para produção de inoculantes. Os efeitos combinados desses fatores (BSF e biochar) agregam vários benefícios ao sistema solo-planta. Os resultados desta revisão demonstram que os aditivos do biochar têm grande potencial como um veículo para inoculação de PSB. No entanto, estudos de biochar combinado com BSF ainda são incipientes. Pesquisas futuras devem concentrar esforços na exploração de cepas altamente eficientes, otimizando as condições e avaliando várias fontes de resíduos para a produção de biochar e sua eficiência em experimentos de campo.
\end{abstract}

Palavras-chave: Fósforo disponível; Microrganismos solubilizantes; Inoculantes.

\title{
Resumen
}

El fósforo (P) juega un papel vital en muchos aspectos del crecimiento y desarrollo de las plantas. La baja cantidad de $\mathrm{P}$ disponible en los suelos agrícolas reduce la productividad de los cultivos y a menudo se aplican fertilizantes fosfatados. Sin embargo, debido a la alta afinidad del P por los constituyentes del suelo, la disponibilidad de este elemento se limita a las plantas. Así, se han estudiado técnicas alternativas, ecológicas y de bajo costo para mejorar la adquisición de $\mathrm{P}$ por los cultivos. Se han destacado los microorganismos capaces de solubilizar $\mathrm{P}$, principalmente bacterias solubilizadoras de fosfato (BSF), ya que ofrecen un enfoque para superar la escasez de $\mathrm{P}$ mediante su introducción en sistemas agrícolas a través de inoculantes. En este trabajo, mostramos el potencial de los microorganismos solubilizantes de $\mathrm{P}$ y sus mecanismos de acción, el potencial de diferentes vehículos de inoculación, destacando también el biocarbón como un producto biológico viable para la producción de inoculantes. Los efectos combinados de estos factores (BSF y biochar) agregan varios beneficios al sistema suelo-planta. Los resultados de esta revisión demuestran que las enmiendas de biocarbón tienen un gran potencial como vehículo para la inoculación de BSF. Sin embargo, los estudios de biocarbón combinado con PSB aún son incipientes. La investigación futura debe centrar los esfuerzos en explorar cepas altamente eficientes, optimizar las condiciones y evaluar varias fuentes de desechos para la producción de biocarbón y su eficiencia en experimentos de campo.

Palabras clave: Fósforo disponible; Microorganismos solubilizantes; Inoculantes.

\section{Introduction}

Phosphorus (P) constitutes molecules such as DNA, ATP, NADPH, and phospholipids of cell membranes, besides participating in processes such as photosynthesis, respiration, carbohydrate metabolism, N2 fixation and protein activation (Vance et al., 2003). However, the interaction of $\mathrm{P}$ with soil constituents, its occurrence in organic forms and its slow rate of diffusion in the soil solution, turns $\mathrm{P}$ into a nutrient little available in the rhizosphere, reducing crop productivity in agricultural soils in different areas of the world (Zhu et al., 2018).

Located in the Neotropical zones, Brazilian soils have negligible amounts of $\mathrm{P}$ due to its source material and the interactions of this element with the soil, which direct the national agriculture towards the use of substantial amounts of phosphate fertilizers (Embrapa, 2017). Brazil imported about 80\% of the raw material for NPK fertilizers manufacturing in 2019, when around 36.2 million tons are estimated to be sold. The use of fertilizers by Brazilian farmers has grown by around $450 \%$ in the last 30 years (Associação Nacional para Difusão de Adubos, 2020).

With slow mobility, most of the $\mathrm{P}$ is adsorbed to the soil colloids, which lessen the losses from percolation.

Therefore, erosion is the main cause of P losses contained in soil organic matter and colloidal particles (Chintala et al. 2014). The risk of considerable $\mathrm{P}$ losses and the increase in eutrophication rates, due to high phosphate fertilizers accumulation in soils, has been observed in short, medium and long term studies (Oliveira Filho et al., 2020).

Organic P in soil organic matter is a relevant source for plant nutrition (Liang et al., 2017). The dynamics of organic $\mathrm{P}$ in the soil is associated with environmental conditions that influence the microbial activity, which immobilize or 
release the orthophosphate ions (H2PO4), and with the physical-chemical and mineralogical properties of the soils (Santos et al., 2008). According to Gatiboni et al. (2007), the contribution of organic $P$ to plat nutrition is $6 \%$ for soils that received phosphate fertilization and about $43 \%$ for native regions without anthropic influence.

In arable areas with seasonal or regular applications of phosphate fertilizers, pockets of $\mathrm{P}$ occur in the soil due to its adsorption on colloids or immobilization in microbial biomass (Nobile et al., 2020; Oliveira Filho et al., 2020). Such reservoirs are barely available to plants, representing a considerable financial investment, especially in a possible scenario of $\mathrm{P}$ scarcity in the market. Therefore, alternative sources of fertilizers are necessary to reduce dependence on mineral fertilizers (Medeiros et al., 2019).

The amount of mineral fertilizers applied to the soil is increasing every year in order to enhance crop productivity (Lee et al., 2019). Increasing the efficiency of fertilizers in agricultural production requires a multidisciplinary approach, which includes the optimization of fertilizer-soil-plant interaction. Brazil is facing a huge challenge for P management in cultivated soils, to attend the demand of increasing yields but preserving natural resources. However, the high Brazilian dependence upon P fertilizers may represent a unsustainable use of a finite resource (Withers et al., 2018).

In contrast to mineral fertilizers, which require revolve the soil for incorporation, the application of fixing or solubilizing microorganisms is less invasive to the environment, as they are inoculated into the soil with the seeds at sowing. This can reduce the risk of pollution of springs, effluents, and groundwater through eutrophication. The use of phosphate solubilizing microorganisms (PSM) is adaptable to more conservationist and organic production systems, given its biological nature.

A wide variety of organisms are involved in the natural cycle of P. Particularly, microorganisms play an important role, being responsible to turn insoluble P into soluble forms accessible to plants (Zhu et al., 2018). Phosphate solubilizing microorganisms have been the subject of study for decades (Kalayu, 2019). Several species of distinct taxonomic groups are reported as solubilizers (Actinomycetes, Cyanobacteria, Bacteria and Fungi) and among PSM, strains of bacteria have received considerable attention.

Thus, due to the high demand and low efficiency of phosphate fertilizers, beyond the importance of an efficient $\mathrm{P}$ management, is the search for new renewable and sustainable technologies for agriculture and the environment (Withers et al., 2018). There are several scientific articles about the selection of effective microbial strains for P solubilization in different agrosystems and soil types. However, there is still a deficit of papers that associate the effectiveness of low-cost inoculant formula that are accessible to produce. Thereupon, the objective of the present review is (i) to provide knowledge about studies of phosphate-solubilizing bacteria (PSB), (ii) to show what is the nature of an inoculant and what are the different materials commonly used to its production and (iii) to highlight advantages and disadvantages of biochar as a PSB inoculation vehicle.

\section{Methodology}

This study is a narrative review about the perspectives for biochar as a vehicle for inoculation of PSB. Narrative reviews are characterized by critical literature analyses, from a theoretical or contextual point of view (Grant \& Booth, 2009). The selected literatures were extracted from the platforms: SciELO, ScienceDirect, Elsevier, PubMed, SpringerLink and Journal CAPES. Where the following keywords were applied, linked by Boolean operators (AND, OR): "available phosphorus; "solubilizing microorganisms"; "inoculants"; "black carbon" and "biochar".

\section{Development}

\subsection{History of bacterial inoculants}

The microbial inoculant industry delivers more than 25 million doses annually to the Brazilian market (Franchini et al., 
2007), mostly focused on inoculating legumes and only $10 \%$ for growing grasses. These products are the main bio-based material produced and sold in the country, and the use of bacterial inoculants in agriculture is estimated to grow at a rate of $12.5 \%$ per year (Owen et al., 2015; Howieson \& Dilworth, 2016).

The use of bacterial inoculants in agriculture has been traced for centuries. In remote times, farmers realized that the production of legumes could increase the yield of the subsequent harvest compared to areas without previous cultivation of legumes. At the end of the $19^{\text {th }}$ century, the knowledge acquired from this practice was used to develop a recommended method for the inoculation of legumes in the United States of America (Smith, 1992). Later, the discovery of N2 fixation by legumes and the isolation of rhizobia from the root nodules of these plants allowed the practice of bacterial inoculation (Cardoso \& Estrada-Bonilla, 2019).

In 1895, Nobbe and Hiltner developed techniques to reproduce Rhizobium spp. in the laboratory and registered the first patent with these microorganisms, starting the production of these inoculants for large scale use (Hungria et al., 2005). Therefore, the commercialization of bacterial inoculants started in 1898 (Cardoso \& Estrada-Bonilla, 2019), and the practice of Rhizobium inoculation became common since then.

At the end of the 1970s, Döbereiner and Day (1976) described the potential of the Azospirillum genus for promoting the development of non-leguminous plants. Bashan (1990) gathered data that demonstrated positive effects of Azospirillum inoculation for corn yield in the field, concluding that the responses were quite substantial due to biological nitrogen fixation. After observations that the promotion of plant growth caused by inoculation with Azospirillum sp. was mainly due to the promotion of root growth and not to nitrogen fixation (Okon \& Labandera-Gonzalez, 1994), the experimental objectives and designs have been changed.

Döbereiner and team isolated the Gluconacetobacter diazotrophicus bacteria in sugarcane plants in the 1990s (Cavalcanti \& Döbereiner, 1988). From there, it was possible to isolate and identify endophytic bacteria in samples of stems, leaves and roots, capable of colonizing sugarcane plants such as G. diazotrophicus (Reis et al., 1994), Herbaspirillum seropedicae and H. rubrisubalbicans (Olivares et al., 1996), Azospirillum spp. and new species of the Burkholderia genus (Perin et al., 2006).

Moreover, the co-inoculation of bacteria is already used in countries such as South Africa and Argentina, but studies are still incipient in Brazil. Co-inoculation provides greater root growth, in addition to greater nodulation potential and an efficient response in the interaction of diazotrophic bacteria, especially with the species Azospirillum brasilense and Bradyrhizobium japonicum (Zuffo et al., 2016). Other benefits of these bacteria are the ability to penetrate plant roots, the antagonism to phytopathogens, association with various grasses such as corn, production of phytohormones and tolerance to temperature variations (Araújo, 2008).

In addition to the mixtures of bacterial strains used in the formulation of inoculants, other groups were investigated alone or through co-inoculation, such as Bacillus (Szilagyi-Zecchin et al., 2015) and its association with fungi of the genus Trichoderma (Chagas et al., 2017) and bacteria belonging to Pseudomonas (Liffourrena et al., 2018; Manzoor et al., 2017), Acetobacter (Florentino et al., 2017) and various types of co-inoculation with Azospirillum and rhizobia (Galindo et al., 2018).

The first bacterial inoculants specific to solubilize P date back to 1950, when a product known as "Fosfobacterin", derived from the mixture of kaolin and Bacillus megatherium var. phosphaticum, was released in the market in the former Soviet Union and Eastern Europe, increasing the mineralization of P in the soil by $20 \%$ (Kucey et al., 1989). However, these results were not confirmed by studies developed in the following years, in other countries such as the USA (Kucey et al., 1989). In several countries (Australia, Canada, Brazil, USA and Russia), since the 1950s, there are records of products based on bacteria such as Acidithiobacillus spp., Bacillus spp. and fungi such as Penicillium bilaji and P. radicum, aiming at the solubilization of $\mathrm{P}$, however, in most cases the results are inconclusive and contradictory (Mendes et al., 2003). 
Studies that explain the interactions between $\mathrm{P}$ and microorganisms have received a special attention, since phosphate solubilizing microorganisms are alternatives to improve the efficiency of P sources in the soil (Massenssini et al., 2015). Studies have been exploring the improved use of nutrients in the soil, by means of microorganisms able to solubilize P (Cisneros-Rojas et al., 2017) and potassium (K) (Bagyalakshmi et al., 2017). Dworzanski et al. (2006) registered the first patent using Bacillus megaterium, B. cereus and B. pectobacterium for dissolving $\mathrm{P}$ and $\mathrm{K}$, fixing nitrogen and promoting plant growth, aiming to develop a multifunctional biofertilizer. The dissolution effects of $\mathrm{P}$ and $\mathrm{K}$ were proven in a greenhouse experiment; however, the product was not tested in the field (Dworzanski et al., 2006).

In 2016, the first inoculant that was successful for solubilization of P (BiomaPhos $®$ ) with Brazilian technology was launched. The product is the result of the mixture of two bacterial strains (Bacillus megaterium and B. subtilis). The inoculation with these microorganisms can accelerate the release into the rhizosphere of non-available inorganic or organic $\mathrm{P}$ and enrich the soil biologically, thus increasing crops yields (Paiva et al., 2020). In corn cultivation in the cities of Santa Maria-RS and PalotinaPR, the mixture of BiomaPhos ${ }^{\circledR}$ with phosphate fertilization using $50 \%$ of the recommended dose, resulted in gains of $28 \%$ on yield, compared to the isolate effects of treatments only with phosphate fertilizer or the isolate strains (Paiva et al., 2020). In addition, products containing Bacillus strains are more stable in the soil due to the ability of Bacillus to form endospores, which allows the bacteria to resist extreme abiotic conditions, such as changes in $\mathrm{pH}$ and temperatures and the presence of pesticides (Bahadir et al., 2018).

The Brazilian Ministry of Agriculture, Livestock and Supply (MAPA, 2011) provides a list of microorganisms authorized for the production of inoculants. Biological inoculants are evaluated in accordance with prerequisites established by MAPA, following the instructions established by regulation no. 13/2011. The MAPA estimates that approximately 150 strains of microorganisms have characteristics that fit the pre-established parameters and have been used in the development of inoculants for different cultures.

\subsection{P-solubilizing bacteria}

In 1948 Pikovskaya discovered the role played by bacteria in the biogeochemical cycle of $\mathrm{P}$, by mineralizing organic $\mathrm{P}$ and solubilizing insoluble inorganic phosphate. This study paved the way for broader research on bacterial genera that have this ability (Zhu et al., 2018), the biochemical processes involved (Kumar, 2016; Ameen et al., 2019), geographic location (Zhu et al., 2018) and environmental conditions in which each strain presents better performance and is able to survive (Prabhu et al., 2019).

Among the species reported as P solubilizers, those classified in the genera Azospirillum, Bacillus, Burkholderia, Enterobacter, Pseudomonas and Rhizobium (Table 1) stand out for their representativeness in studies. Bacteria of the genus Bacillus, Pseudomonas and Rhizobium are among the most abundant in the rhizosphere (Cheng et al., 2017). 
Table 1. Phosphate-solubilizing bacteria species.

\begin{tabular}{|c|c|}
\hline Species & References \\
\hline Azospirillum brasilense & Rodriguez et al., 2004; Moraes et al., 2019 \\
\hline A. lipoferum & Rodriguez et al., 2004 \\
\hline Bacillus circulans & Sharma et al., 2013; Satyaprakash et al., 2017 \\
\hline B. megaterium & $\begin{array}{l}\text { Chen et al., 2006; Sharma et al., 2013; Satyaprakash et al., } \\
\text { 2017; Hajjam et al., } 2017\end{array}$ \\
\hline B. polymyxa; B. subtilis & $\begin{array}{l}\text { Khan et al., 2009; Sharma et al., 2013; Thakur et al., 2014; } \\
\text { Hajjam et al., 2017 }\end{array}$ \\
\hline B. pulvifaciens & Arora \& Gaur 1979 \\
\hline B. coagulans; B. fusiformis; B. pumilus; B. chitinolyticus & Sharma et al., 2013 \\
\hline B. sircalmous & Khan et al., 2009; Kumar et al., 2018 \\
\hline Burkholderia cenocepacia & Liu et al., 2019; You et al., 2020; \\
\hline B. cepacia & Pande et al., 2019 \\
\hline B. multivorans & Zeng et al., 2017 \\
\hline B. stabilis & Hong-Sin et al., 2018 \\
\hline B. tropica & Anillo et al., 2016; Bernabeu et al., 2016 \\
\hline Enterobacter asburiae & Kumar et al., 2016 \\
\hline E. cloacae & Borham et al., 2017 \\
\hline E. ludwigii & Lee et al., 2019 \\
\hline Thiobacillus ferrooxidans & Sharma et al., 2013 \\
\hline Pseudomonas canescens & Alam et al., 2002 \\
\hline P. putida & $\begin{array}{l}\text { Alam et al., 2002; Ghaderi et al., 2008; Khan et al., 2009; } \\
\text { Thakur et al., } 2014\end{array}$ \\
\hline P. calcis & Sharma et al., 2013 \\
\hline P. fluorescens & $\begin{array}{l}\text { Ghaderi et al., 2008; Khan et al., 2009; Sharma et al., 2013; } \\
\text { Thakur et al., 2014; Hajjam et al., } 2017\end{array}$ \\
\hline P. striata & $\begin{array}{l}\text { Khan et al., 2009; Sharma et al., 2013; Thakur et al., 2014; } \\
\text { Hajjam et al., } 2017\end{array}$ \\
\hline Pantoea agglomerans & Son et al., 2006 \\
\hline Rhizobium meliloti & Sharma et al., 2013 \\
\hline R. leguminosarum & $\begin{array}{l}\text { Afzal \& Bano 2008; Walpola \& Yoon 2012; Hajjam et al., } \\
2017\end{array}$ \\
\hline Mesorhizobium mediterraneum & Peix et al., 2001 \\
\hline
\end{tabular}

Source: Authors.

In addition of improving $\mathrm{P}$ availability to plants, the PSB are also capable of mobilizing heavy metals toxic to plants and humans (Mohamed \& Almaroai, 2017; Teng et al., 2019), generating benefits to the biodiversity of the micro and macrofauna of the soil, thus enabling cultivation in previously contaminated soils. In these circumstances, Ahemad (2015) assesses the use of PSB as an economically viable alternative, causing less impact on the environment, without compromising the soil structure, nor its microfauna, compared to mineral inputs traditionally used.

Irfan et al. (2019), applying a mix of different strains of PSB and carriers of inoculum in saline soil in maize crop, observed a significant increase in plant growth and corn production, for all treatments in relation to control regardless the level of salinity. Shahzad et al. (2017) observed similar results with wheat, due to the production of ACC deaminase by PSB, which catalyze ACC synthase enzymes released by plants under stress conditions, reducing the effects of high salt concentration. According to Nadeem et al. (2013), this process also favors the growth of the introduced microbial community, since the degradation of ACC synthase produces $\alpha$-ketobutyrate and as a by-product ammonia, which is absorbed by microorganisms promoting a positive symbiotic relationship.

Several species of distinct taxonomic groups are reported as P solubilizers (Actinomycetes, Cyanobacteria, Bacteria and Fungi) and among them the strains of bacteria have received considerable attention. With approximately 101 to 1010 individuals per gram of soil within soil microbial communities, bacterial populations can exceed 2,000 kg ha-1 of the live weight in these habitats, while PSB can represent between 1 and 50\% of the total communities of these microorganisms (Khan et al., 2009). 
The physiological characteristics and biochemical properties of specimens of bacteria make these microorganisms colonizers of a wide variety of habitats. With a cosmopolitan distribution, species of PSB have been mainly isolated from rhizospheric soil samples. However, evidence demonstrates a symbiotic relationship with several groups of plants, also being able to occur as endophytes (Donato et al., 2019).

Vassilev et al. (2012) reported the occurrence of P solubilization by bacteria under adverse conditions. Abiotic stresses such as water scarcity, $\mathrm{pH}$ changes (high or low), salinity and temperatures, apparently, did not exert negative influences on the solubilization phenomenon. Prabhu et al. (2019) highlight these characteristics and classify tolerant and extremophile phosphate solubilizing bacteria as potential bioinoculants, especially in anthropized agricultural areas. The effectiveness of PSB species has been reported in several conditions, such as high levels of salinity (Nakbanpote et al., 2014) and pH variations (Prabhu et al., 2018).

Benefits of the inoculation of PSB species have been reported in several crops, promoting the growth and development of eucalyptus (Foltran et al., 2019), cotton (Akhtar et al., 2010), beans (Belhardi et al., 2018), tomatoes (Anillo et al., 2016), and soybeans (Belhardi et al., 2018).

\subsection{P solubilization mechanisms}

Variations in the ability to solubilize P in soil, by PSB taxa, have been discussed in recent years (Gupta et al., 2012; Massenssini et al., 2015; Zhu et al., 2018). The increase in P availability has been documented, mainly, by species of the genera Pseudomonas, Azotobacter, Burkholderia, Bacillus and Rhizobium (Anillo et al., 2016; Hajjam \& Cherkaoui, 2017; Belhardi et al., 2018). According to Zhu et al. (2018), the solubilization capacity can be attributed to factors such as species, lineage, soil properties (inherent and seasonal) and plant species present in the area. However, although the increase in productivity related to the promotion of $\mathrm{P}$ availability by the application of these microorganisms is widely recognized (Hajjam \& Cherkaoui 2017; Belhardi et al., 2018), the mechanisms concerning this phenomenon are not entirely understood.

The microbial synthesis of different exudates, including organic acids, metabolites, and enzymes, has emerged as essential factors to $\mathrm{P}$ solubilization (Behera et al., 2014). Additionally, the reduction of soil $\mathrm{pH}$, chelation and mineralization have been reported as important mechanisms for this phenomenon (Kalayu, 2019) (Figure 1). 
Research, Society and Development, v. 11, n. 1, e36211124885, 2022

(CC BY 4.0) | ISSN 2525-3409 | DOI: http://dx.doi.org/10.33448/rsd-v11i1.24885

Figure 1. Mechanisms of inorganic and organic phosphate solubilization by bacteria.

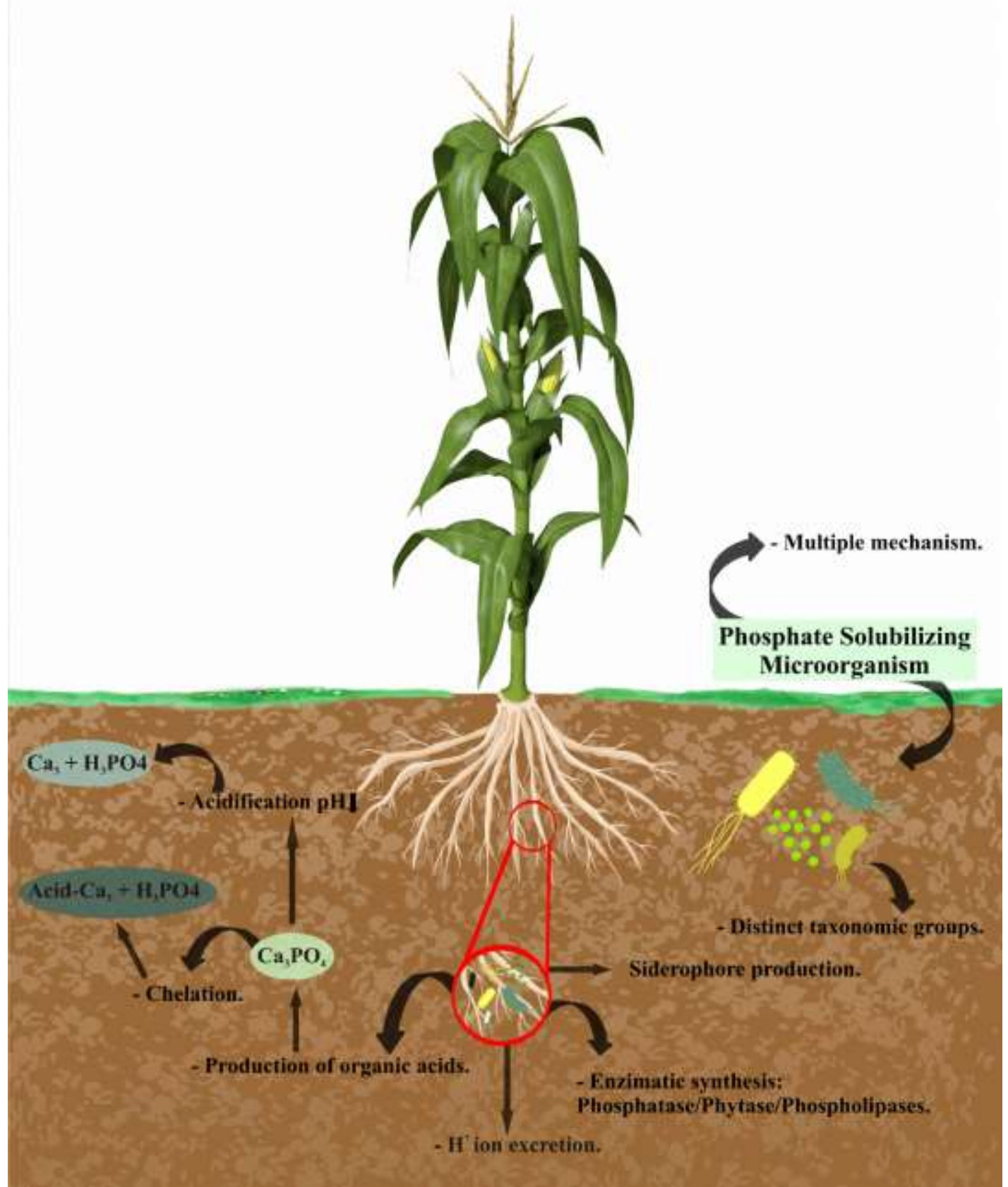

Source: Adapted from Prabhu et al. (2019).

In general, the action of solubilizing P by PSB would be closely related to four factors: i) synthesis of organic acids such as gluconic, isovaleric, oxalic, tartaric, succinic, citric, fumaric and butyric; ii) $\mathrm{H}+$ proton extrusion mechanism, from the assimilation of $\mathrm{NH} 4+$; iii) production of exopolysaccharides and iv) production of siderophores with high affinity for iron (Posso $\&$ De Prager, 2017). 
Products of the bacterial metabolism, organic acids influence the natural dynamics of the P cycle. The synthesis of these acids has a strong positive correlation with the solubilization index and the decrease in soil pH (Satyaprakash et al., 2017). Studies conducted with bacteria of the genus Acinetobacter, have shown the solubilization of phosphates from gluconic, oxalic and butyric acids, providing better development of crops such as cabbage, cucumber, daisy, barley, wheat, and chickpeas (Kang et al., 2009; Ogut et al., 2010). According to Kalayu (2019), the efficiency of solubilization depends on the resistance and nature of the acids. Gluconic acid is reported as the main organic acid synthesized by PSB, such as Acinetobacter sp., Pseudomonas sp., Enterobacter agglomerans (Erwinia herbicola) and Burkholderia cepacia (Zhu et al., 2018).

Among the processes and mechanisms of $\mathrm{P}$ solubilization, chelating substances play an important role. The acids synthesized by PSB as 2-keto-gluconic acid, humic acid and fulvic acid convert insoluble forms of phosphate by cation chelation (Khan et al., 2009; Prabhu et al., 2019). These acids are strong chelators of tricalcium insoluble phosphates (Ca3(PO4)2), aluminum phosphate (AlPO4) and iron phosphate (FePO4) (Khan et al., 2009).

The solubilization of organic phosphate in the soil occurs through the action of microbial enzymes (Jorquera et al., 2008). The production of extracellular enzymes such as phosphoesterases, phosphodiesterases, phytases and phospholipases by species of Bacillus, Streptomyces and Pseudomonas, for example, mineralize complex organic phosphates converting them into phosphate ions accessible for assimilation (Khan et al., 2009; Walpola \& Yoon, 2012). Satyaprakash et al. (2017) also reported the production of siderophores, which hydrolyze organic P. However, Prabhu et al. (2019) warn that the relationship between siderophores synthesis and phosphate solubilization is not yet fully understood.

\subsection{What a biological inoculant must have}

Due to the expansion of agriculture and the high demand for fertilizers, alternatives that guarantee environmental security and that are economically viable are demanded by farmers. Among some of these alternatives, biofertilizers in the form of inoculants are characterized by being eco-sustainable, having low cost, however, they need specific formulation for use (Owen et al., 2015). Inoculants are inexpensive products, easy to purchase, have positive results regarding use in agriculture, providing great gains in production and savings in mineral fertilizers.

The success of microbial development after introduction of inoculants into the soil is linked to abiotic factors such as $\mathrm{pH}$, temperature, humidity, and biotic factors such as competition for nutrients, substrates, predators and the presence of pathogens that compromise bacterial survival in the rhizosphere (Sivakumar et al., 2014; Reetha et al., 2014).

The microbial inoculant is a product that contains microorganisms favorable to plant growth. Classified as solids (powder, peat being a support for bacteria) and fluids (liquids, where bacteria already have their metabolic processes stabilized via cell protectors) (Prabhu et al., 2019).

According to the definition of the Brazilian Ministry of Agriculture, Livestock and Supply (MAPA), in Decree 4.954 (2004), Art. 2, item V, inoculant is all the biological input with microorganisms capable of performing beneficial and necessary activities for the development of plants, produced in accordance with protocols stipulated by the Network of Laboratories for the Recommendation, Standardization and Diffusion of Technology of Microbial Inoculants of Agricultural Interest (RELARE). They are cheap products, offered in liquid, gel, peat and even new formulations. The inoculant in its liquid formula can be applied via seed and sowing furrow; the peat-based inoculant can only be applied via seed (Silva et al., 2009).

This material must have three essential characteristics: promote satisfactory bacterial development, keep the cells of microorganisms viable for a certain period, and ensure the gradual release of a bacterial population that will be beneficial to plants (Bashan et al., 2014; Cardoso \& Estrada-Bonilla, 2019)

Biofertilizer is a liquid organic fertilizer, which can be produced in aerobic or anaerobic medium from a mixture of organic materials (manure, fruits, milk), minerals (macro and micronutrients) and water, from the fermentation of agricultural 
residues or of animal waste. These biofertilizers can replace or complement chemical fertilization and can be used in soil or foliar applications (Sousa et al., 2013).

The term biofertilizer is also included in the Normative Instruction (IN) 64 of 2008 from the MAPA, which approves the technical regulation and the substances allowed for organic production systems. Biofertilizer is then defined as "product containing active components or biological agents, capable of acting directly or indirectly on all or part of the cultivated plants, improving the performance of production system and that is free of substances prohibited by the organic regulation". Thus, this normative instruction incorporates beneficial microorganisms (fungi and bacteria) that can have a stimulating effect and could be considered biofertilizers in organic production.

\subsection{Inoculant formulations}

The inherent heterogeneity of any soil is the main obstacle to inoculation. The introduced bacteria can find niches in the plant rhizosphere colonized by other microorganisms. These introduced and unprotected bacteria must compete with the native microflora that is often better adapted and, in most cases, cannot withstand the predation of soil microfauna. In response, an important role for any inoculant formulation is to provide a more suitable microenvironment, combined with physical protection for an extended period (Bashan et al., 2016).

The potential substance must have stable physicochemical characteristics, which guarantee the integrity of its organoleptic properties, such as the conservation of its shape, composition, and molecular structure, as well as odor and tex ture, in order to not affect the number of viable cells, ensuring that after applying the product it will perform as expected (Arora \& Mishra, 2016; Malusá et al., 2016).

Even with integrity, candidates for inoculum vehicles should not be a medium devoid of nutrients. It has to contain specific substances and chemical elements that can meet part of the energy demand that the microbial community needs to remain viable (Cortés-Patiño et al., 2015), as well as being able to present an adequate $\mathrm{pH}$ that promotes maintenance and propagation of microorganisms at the time of application. Inadequate formulations are the main barriers to the approval and commercialization of new inoculants (Stephens \& Rask, 2000), as also the difficulty in adjusting formulas with physical, chemical, and biological characteristics capable of keeping the population of microorganisms viable over time (Silva et al., 2012).

Inoculation vehicles share the same fundamental principle, which is to ensure the survival of the microorganisms of interest, despite varying in physical condition (Husna et al., 2019; Bojkov et al., 2020). To this end, some criteria must be met before any substance or medium can be listed as a potential candidate, especially with regard to formulations that will be commercialized and must meet strict commercial and legislative standards.

Even though they are eligible for possible inoculating medium, raw materials must be significantly abundant, so their extraction and production costs turn them financially viable. Another key point that must be addressed is non-toxicity (Hale et al., 2015) and the use of renewable resources, which ensure continuous and sustainable exploration.

According to Bashan et al. (2014), there are five classes of inoculum-carrying materials: (1) peat, coal, biochar, clay and inorganic soil; 2) waste from plants of various industrial and agricultural origins; (3) inert materials, polymers and treated rock fragments; (4) freeze-dried microbial cultures, mixed with oil and dry bacteria; and (5) inoculating liquids, with the addition of chemicals that improve viscosity, stability, surface tension, function and dispersion.

Liquid formulations are suspensions that contain components that improve the viscosity and stability of the solution (Bashan et al., 2014). The main advantage of this formulation is its easy handling, being preferred by developed countries.

Polymeric formulations have been tested as an industrial substitute for commercial peat. They exhibit several advantageous characteristics including longer shelf life, viability and density of strains, ease of manufacture and better 
performance in the field. Some examples of polymers are chitosan, alginate, agar, bean gum, among others (Bashan et al., 2014).

Peat is the most used worldwide as a rhizobium carrier, in powder or participating in the formulation of organic composts, except in Africa and Asia where this material is expensive. One of the problems of peat is its stability, due to its characteristics in terms of particle size, pH, humidity, shelf life (Deaker et al., 2004; 2011). Another problem is the finite source, since large world reserves of peat with characteristics conducive as vehicles of inoculation are not available. Alternative materials to peat were tested in the years 1980's and 1990's as charcoal, mud, coconut powder, sugar cane filter, but all obtained worse results when compared to peat (Singleton et al., 2002). Although other organic inputs have had positive results, the main obstacle is their availability in quantity to supply the demand of the market.

\subsection{Viability of biochar as a component of microbial inoculants}

Biochar is a fine-grained carbonaceous material with high organic carbon content and largely resistant to microbial decomposition. This material can be obtained through thermal decomposition (pyrolysis) of biomass, under limited oxygen conditions (Medeiros et al., 2020b) and temperature between 300 to $900{ }^{\circ} \mathrm{C}$ (Pandey et al., 2020). Several raw materials can be employed in biochar production, such as crop residues, bark like coffee (Lima et al., 2018), wood scraps (logs, bark, branches), grasses and other residues from agriculture, livestock and agro-industries (Medeiros et al., 2020a).

When applied to the soil, the biochar creates a carbon reserve, serving as a network that removes $\mathrm{CO} 2$ from the atmosphere and stores it in the soil in the form of recalcitrant carbon (Lehmann \& Joseph 2009), makes the soil suitable for carbon sequestration. Biochar has been widely stimulated and recognized as a $\mathrm{C}$ sequestering vehicle, and the United Nations meeting on climate change in Copenhagen describes in the draft negotiating text: "We must pay special attention to the role of soils in carbon sequestration, including the use of biochar and carbon sinks in arid lands".

Furthermore, the application of biochar in agriculture brings several benefits as it helps to reduce nutrients leaching as well plant requirements of irrigation and fertilizers, due to the capacity of retaining nutrients and water (Lima et al., 2018; Razzaghi et al., 2020); acts as a soil conditioner (Aamer et al., 2020; Ye et al., 2020); increases the cation exchange capacity, as it presents negatively charged functional groups on its surface (Lara et al., 2013) and acts on soil aggregation (Amoah-Antwi et al., 2020). Biochar also increases carbon stability, adsorption and / or complexation of organic matter and toxic components and improves the microbial health of the soil (Li et al., 2017). The high specific surface area and the porosity of the biochar create an environment that promotes microbial growth, such as bacteria, ectomycorrhizal fungi, mycorrhizal fungi, and arbuscular mycorrhizal fungi (Palansooriya et al., 2019), enzymatic activities and nutrient cycling (Wang et al., 2016), and as an alternative for suppressing plant diseases (Debode et al., 2020).

As $\mathrm{P}$ is normally released at temperatures higher than $800^{\circ} \mathrm{C}$, it is most likely that pyrolysis is not sufficient to turn it available, therefore, P can be retained in the biochar in inorganic or organic form (Schmalenberger et al., 2016). Recent studies suggest that the interaction of biochar in the soil can also influence the availability of $\mathrm{P}$, due to changes in $\mathrm{pH}$, in enzymatic efficiency, in the formation of organo-mineral complexes, which can increase the solubility of $\mathrm{P}$ through changes induced in the soil microbial community (Du et al., 2019; Li et al., 2020; Shi et al., 2020). Given these advantages for the physical, chemical, and biological properties of the soil (Butnan et al., 2015), biochar emerges as a promising and ecologically favorable alternative for enhancing yields of agricultural crops (Butnan et al., 2015; Martins Filho, 2020).

Moreover, biochar can be an efficient inoculum component for some microorganisms (Medeiros et al., 2020a). Qian et al. (2020), when evaluating the biotransformation of $\mathrm{P}$ in the biochar on the behavior of Pseudomonas putida, proved that biochar can be a potential $\mathrm{P}$ fertilizer. However, it must be taken into account the type of raw material and temperature used for biochar production, which influences its performance. Medeiros et al. (2020a) evaluated biochars from coffee residues and found that it can be an inoculation vehicle for Trichoderma aureoviridae, a multifunctional microorganism in the soil. Yan et al. (2020) 
reinforces the statement that the increase in the availability of $\mathrm{P}$ through biochar varies according to the residue used and the pyrolysis temperature, emphasizing that higher temperatures favor the supply of $\mathrm{P}$.

The patent literature shows in document CN108083908 (A) that biochar mixed with maleic acid, ammonium nitrate and a mixed microbial agent composed of saccharromicets, photosynthetic bacteria, Bacillus subtilis, rhizobia, Trichoderma viride and Bacillus is used as a microbial fertilizer, biofertilizer and / or soil modifier. Another product contains 95-98\% biochar and 2-4\% probiotic agent, consisting of Paenibacillus polymyxa, Trichoderma strains, rhizobia, nitrogen-fixing bacteria, phosphate solubilizers, potassium, cellulose decomposers, antibiotic, and photosynthetic generators (CN102660291 (A). Another bean husk biochar was inoculated with Trichoderma aureoviride for the formulation of a biofertilizer (BR1020180163680). The biochar was also used to fix a mixture of microbial agents such as Shewanella putrefaciens, Geobacter metallireducens, Trichoderma viride and Trichoderma harzianum and a protective bacterium, Bacillus subtilis (CN109609417 (A).

In this sense, biochar can be an economical and environmentally friendly alternative, as it serves as a tool for reusing waste generated by the agribusiness that generates 200 million tons of biomass from waste in Brazil (Martinez et al., 2019). In view of the extensive literature showing positive results from the use of biochar in agricultural soils, it was considered an ecological fertilizer for sustainable and modern agriculture (Chen et al., 2018), and as a member of microbial inoculants (Medeiros et al., 2020a, b).

\section{Conclusion}

As most Brazilian soils are deficient in phosphorus and the phosphate sources are non-renewable natural resources, the efficient use of $\mathrm{P}$ in agriculture is essential. The production of biofertilizers and bioinoculants are strategies for introducing microorganisms able to improve $\mathrm{P}$ availability to plants. In addition, the selection of strains of bacteria that are highly efficient in solubilizing $\mathrm{P}$ and adapting to different agrosystems are crucial to achieve the successful performance of $\mathrm{P}$ supply to plants. The use of biochar brings several benefits to the soil and plants, as well as to the environment, as a tool to recycle residues from the agribusiness. This review showed how biochar can be promising as component of a possible inoculant and for the formulation of new products. However, studies aiming the use of biochar combined with P-solubilizing bacteria is still incipient. Future research should focus efforts on exploring highly efficient strains, optimizing conditions, and assessing several sources of waste for production of biochar and their efficiency in field experiments.

\section{Acknowledgments}

We thank fellowships and grants from CNPq (PQ:313174/2018-0; 426497/2018-0; 307335/2017-8; ONDACBC:465764/2014-2 and NEXUS: 441305/2017-2), and FACEPE (APQ-0223-5.01/15; APQ-0419-5.01/15; APQ-04315.01/17; APQ-0498-3.07/17). This study was financed in part by the Coordenação de Aperfeiçoamento de Pessoal de Nível Superior - Brasil (CAPES 88887.736369/2017-00).

\section{References}

Aamer, M., Shaaban, M. Hassan, M. U., Guoqin, H., Ying, L., Ying, T. H., Rasul, F., Qiaoying, M., Zhuanling, L., Rasheed, A. \& Peng, Z. (2020). Biochar mitigates the $\mathrm{N} 2 \mathrm{O}$ emissions from acidic soil by increasing the nosZ and nirK gene abundance and soil pH. Journal of Environmental Management, $255,109891$. https://doi.org/10.1016/j.jenvman.2019.109891

Ahemad, M. (2015). Phosphate-solubilizing bacteria-assisted phytoremediation of metalliferous soils: a review. 3 Biotech, 5(2), 111-121. https://doi.org/10.1007/s13205-014-0206-0

Akhtar, N., Iqbal, A., Qureshi, M. A. \& Khan, K. H. (2010). Effect of phosphate solubilizing bacteria on the phosphorus availability and yield cotton. Journal of Scientific Research, 40(1),15-24 
Ameen, F., AlYahya, S.A., AlNadhari, S., Alasmari, H., Alhoshani, F. \& Wainwright, M. (2019). Phosphate solubilizing bacteria and fungi in desert soils: species, limitations and mechanisms. Archives of Agronomy and Soil Science, 65(10), 1446-1459. https://doi.org/10.1080/03650340.2019.1566713

Amoah-Antwi, C., Kwiatkowska-Malina, J., Thornton, S.F., Fenton, O., Malina, G. \& Szara, E. (2020). Restoration of soil quality using biochar and brown coal waste: A review. Science of the Total Environment, 722, 137852. https://doi.org/10.1016/j.scitotenv.2020.137852

Anillo, H. J. B., Zentella, M. L. C. \& Sierra, G. T. (2016). Burkholderia tropica Una Bacteria Con Gran Potencial Para Su Uso En La Agricultura. TIP Revista Especializada en Ciencias Químico-Biológicas, 19, 102-108. https://doi.org/10.1016/j.recqb.2016.06.003

Araújo, F. F. (2008). Seed inoculation with Bacillus subtilis, formulated with oyster meal and growth of corn, soybean and cotton. Ciência e Agrotecnologia, $32(2), 456-462$

Arora, N. K. \& Mishra, J. (2016). Prospecting the roles of metabolites and additives in future bioformulations for sustainable agriculture. Applied Soil Ecology, 107, 405-407. https://doi.org/10.1016/j.apsoil.2016.05.020

Bagyalakshmi, B., Ponmurugan, P. \& Balamurugan, A. (2017). Potassium solubilization, plant growth promoting substances by potassium solubilizing bacteria (KSB) from southern Indian Tea plantation soil. Biocatalysis and Agricultural Biotechnology, 12, 116-124. https://doi.org/10.1016/j.bcab.2017.09.011

Bahadir, P. S., Liaqat, F. \& Eltem, R. (2018). Plant growth promoting properties of phosphate solubilizing Bacillus species isolated from the Aegean Region of Turkey. Turkish Journal of Botany, 42(2), 183-196. https://doi.org/10.3906/bot-1706-51

Bashan, Y. \& Levanony, H. (1990). Current status of Azospirillum inoculation technology: Azospirillum as a challenge for agriculture. Canadian Journal of Microbiology, 36(9), 591-608. https://doi.org/10.1139/m90-105

Bashan, Y., De-Bashan, L., Prabhu, S. R. \& Hernandez, J. P. (2014). Advances in plant growth-promoting bacterial inoculant technology: formulations and practical perspectives (1998-2013). Plant and Soil, 378, 1-33. https://doi.org/10.1007/s11104-013-1956-x

Bashan, Y., De-Bashan, L. E. \& Prabhu, S. R. (2016). Superior polymeric formulations and emerging innovative products of bacterial inoculants for sustainable agriculture and the environment. In: Singh, H., Sarma, B., Keswani, C. (eds) Agriculturally Important Microorganisms. Springer, Singapore. pp 15-46. https://doi.org/10.1007/978-981-10-2576-1_2

Behera, B. C., Singdevsachan, S. K., Mishra, R. R., Dutta, S. K. \& Thatoi, H. N. (2014). Diversity, mechanism and biotechnology of phosphate solubilising microorganisms in mangrove- a review. Biocatalysis and Agricultural Biotechnology, 3, 97-110. https://doi.org/10.1016/j.bcab.2013.09.008

Belhardi, D., Lajudie, P., Ramdani, N., Roux, C. L., Boulila, P., Tisseyre, P., Boulila, A., Benguedouar, A., Kaci, Y. \& Laguerre, G., (2018). Vicia faba L. in the Bejaia region of Algeria is nodulated by Rhizobium leguminosarum sv. viciae, Rhizobium laguerreae and two new genospecies. Systematic and Applied Microbiology, 41, 122-130.

Vassilev, N., Vassileva, M., Martos, V., Del Moral, L. F. G., Kowalska, J., Tylkowski, B. \& Malusá, E. (2020). Formulation of Microbial Inoculants by Encapsulation in Natural Polysaccharides: Focus on Beneficial Properties of Carrier Additives and Derivatives. Frontiers in Plant Science, 11, 270. https://doi.org/10.3389/fpls.2020.00270

Butnan, S., Deenik, J. L., Toomsan, B., Antal, M. J. \& Vityakon, P. (2015). Biochar characteristics and application rates affecting corn growth and properties of soils contrasting in texture and mineralogy. Geoderma, 237, 105-116.https://doi.org/10.1016/j.geoderma.2014.08.010

Cardoso, E. J. B. N. \& Estrada-Bonilla, G. A. (2019). Inoculantes agrícolas. Biotecnologia Industrial: Processos fermentados e enzimáticos, Blucher, São Paulo.

Cavalcante, V. A. \& Döbereiner, J. (1988). A new acid tolerant nitrogen-fixing bacterium associated with sugarcane. Plant and Soil, 108, 23-31. https://doi.org/10.1007/bf02370096

Chagas, L. F. B., Martins, A. L. L., de Carvalho Filho, M. R., de Oliveira Miller, L., de Oliveira, J. C. \& Junior, A. F. C. (2017). Bacillus subtilis and Trichoderma sp. in biomass increase in soybean, beans, cowpea, corn and rice plants. Agri-Environmental Sciences, 3(2), 10-18.

Chen, M., Alim, N., Zhang, Y., Xu, N. \& Cao, X. (2018). Contrasting effects of biochar nanoparticles on the retention and transport of phosphorus in acidic and alkaline soils. Environmental Pollution, 239, 562-570. https://doi.org/10.1016/j.envpol.2018.04.050

Cheng, J., Zhuang, W., Li, N. N., Tang, C. L. \& Ying, H. J. (2017). Efficient biosynthesis of d-ribose using a novel co-feeding strategy in Bacillus subtilis without acid formation. Letters in Applied Microbiology, 64(1), 73-78. https://doi.org/10.1111/lam.12685

Chintala, R., Schumacher, T. E., McDonald, L. M., Clay, D. E, Malo, D. D., Papiernik, S. K., Clay, S. A. \& Julson, J. L. (2014). Phosphorus sorption and availability from biochars and soil/biochar mixtures. Clean-Soil, Air, Water, 42(5), 626-634. https://doi.org/10.1002/clen.201300089

Cisneros-Rojas, C. A., Sánchez-de Prager, M. \& Menjivar-Flores, J. C. (2017). Efecto de bacterias solubilizadoras de fosfatos sobre el desarrollo de plántulas de café. Agronomía Mesoamericana, 28(1), 149-158. https://doi.org/10.15517/am.v28i1.22021

Cortés-Patiño, S. \& Bonilla, R. R. (2015). Polymers selection for a liquid inoculant of Azospirillum brasilense based on the Arrhenius thermodynamic model. African Journal of Biotechnology, 14(33), 2547-2553. https://doi.org/10.5897/ajb2015.14777

Donato, A., Maia, T. F., Conto, T. D., Pereira, M. G. \& Fraga, M. E. (2019). Microbiota produtora de fitase isolada de solo e serapilheira do Bioma Cerrado. Ciência Florestal, 29(3), 1270-1281. https://doi.org/10.5902/1980509815586

Deaker, R., László, M., Rose, M. T., Amprayn, K., Ganisan, K., Tran, T. K. C., Nga, V. T., Cong, P. T., Hien, M. T. \& Kennedy, I. R. (2011). Practical methods for the quality control of inoculant biofertilisers. Centre for International Agricultural Research, Australian.

Deaker, R., Roughley, R. J. \& Kennedy, I. R. (2004). Legume seed inoculation technology-a review. Soil Biology \& Biochemistry, 36(8), 1275-1288. https://doi.org/10.1016/j.soilbio.2004.04.009 
Debode, J., Ebrahimi, N., D'Hose, T., Cremelie, P., Viaene, N. \& Vandecasteele, B. (2020). Has compost with biochar added during the process added value over biochar or compost to increase disease suppression? Applied Soil Ecology, 153, 103571. https://doi.org/10.1016/j.apsoil.2020.103571

Döbereiner, J. \& Day, J. M. (1976). Associative symbiosis in tropical grass: Characterization of microorganisms and dinitrogen fixing sites. Symposium on Nitrogen Fixation, Washington State Univ Press.

Du, J., Zhang, Y., Qu, M., Yin, Y., Fan, K., Hu, B., Zhang, H., Wei, M. \& Ma, C. (2019). Effects of biochar on the microbial activity and community structure during sewage sludge composting. Bioresource Technology, 272, 171-179. https://doi.org/10.1016/j.biortech.2018.10.020

Dworzanski, J. P., Deshpande, S. V., Chen, R., Jabbour, R. E., Snyder, A. P., Wick, C. H. \& Li, L. (2006). Mass spectrometry-based proteomics combined with bioinformatic tools for bacterial classification. Journal of Proteome Research, 5(1), 76-87. https://doi.org/10.1021/pr050294t.s001

EMBRAPA - Empresa Brasileira de Pesquisa Agropecuária. Dependência externa de fertilizantes NPK é debatida em Audiência Pública. Embrapa Notícias (2017)

Florentino, L. A., Silva, A. B., Landgraf, P. R. \& Souza, F. R. (2017). Inoculação de bactérias produtoras de ácido 3 -indol acético em plantas de alface (Lactuca sativa L.). Revista Colombiana de Ciencias Hortícolas, 11(1), 89-96. https://doi.org/10.17584/rcch.2017v11i1.5780

Foltran, E. C., Rocha, J. H. T., Bazani, J. H., de Moraes Goncalves, J. L., Rodrigues, M., Pavinato, P. \& Garcia-Mina, J. M. (2019). Phosphorus pool responses under different $\mathrm{P}$ inorganic fertilizers for a eucalyptus plantation in a loamy Oxisol. Forest Ecology and Management, 435, 170-179. https://doi.org/10.1016/j.foreco.2018.10.053

Franchini, J. C., Crispino, C. C., Souza, R. A., Torres, E. \& Hungria, M. (2007). Microbiological parameters as indicators of soil quality under various soil management and crop rotation systems in southern Brazil. Soil and Tillage Research, 92(1-2), 18-29. https://doi.org/10.1016/j.still.2005.12.010

Galindo, F. S., Teixeira Filho, M., Buzetti, S., Ludkiewicz, M. G., Rosa, P. A. \& Tritapepe, C. A. (2018). Technical and economic viability of co-inoculation with Azospirillum brasilense in soybean cultivars in the Cerrado. Revista Brasileira de Engenharia Agrícola e Ambiental, 22(1), 51-56. https://doi.org/10.1590/1807-1929/agriambi.v22n1p51-56

Gatiboni, L. C., Kaminski, J., dos Santos Rheinheimer, D. \& Flores, J. P. C. (2007). Bioavailability of soil phosphorus forms in no tillage system. Revista Brasileira de Ciência do Solo, 31(4), 691-699.

Gupta, M., Kiran, S., Gulati, A., Singh, B. \& Tewari, R. (2012). Isolation and identification of phosphate solubilizing bacteria able to enhance the growth and aloin-A biosynthesis of Aloe barbadensis Miller. Microbiological Research, 167(6), 358-363. https://doi.org/10.1016/j.micres.2012.02.004

Grant, M. J. \& Booth, A. (2009). A typology of reviews: an analysis of 14 review types and associated methodologies. Health Information \& Libraries Journal, 26(2), 91-108. https:// doi.org/10.1111/j.1471-1842.2009.00848.x

Hajjam, Y. \& Cherkaoui, S. (2017). The influence of phosphate solubilizing microorganisms on symbiotic nitrogen fixation: Perspectives for sustainable agriculture. Journal of Materials Science, 8(3), 801-808.

Hale, L., Luth, M. \& Crowley, D. (2015). Biochar characteristics relate to its utility as an alternative soil inoculum carrier to peat and vermiculite. Soil Biology \& Biochemistry, 81, 228-235. https://doi.org/10.1016/j.soilbio.2014.11.023

Howieson, J. G. \& Dilworth, M. J. (2016). Working with rhizobia. Centre for International Agricultural Research, Canberra, Australian.

Hungria, M., Franchini, J. C., Campo, R. J. \& Graham, P. H. (2005). The importance of nitrogen fixation to soybean cropping in South America. Nitrogen Fixation in Agriculture, Forestry, Ecology, and the Environment, 25-42. https://doi.org/10.1007/1-4020-3544-63

Husna, N., Budianta, D. \& Napoleon, A. (2019). Evaluation of several biochar types as inoculant carrier for indigenous phosphate solubilizing microorganism from acid sulphate soil. Journal of Ecological Engineering, 20(6), 1-8. https://doi.org/10.12911/22998993/109078

Irfan, M., Zahir, A. Z., Asghar, H. N., Khan, M. Y., Ahmad, H. T. \& Ali, Q. (2019). Effect of multi-strain bacterial inoculation with different carriers on growth and yield of maize under saline conditions. International Journal of Agriculture and Biology, 22, 1407-1414.

Jorquera, M. A., Hernández, M. T., Rengel, Z., Marschner, P. \& de la Luz Mora, M. (2008). Isolation of culturable phosphobacteria with both phytatemineralization and phosphate-solubilization activity from the rhizosphere of plants grown in a volcanic soil. Biology and Fertility of Soils, 44(8), 1025. https://doi.org/10.1007/s00374-008-0288-0

Kalayu, G. (2019). Phosphate solubilizing microorganisms: promising approach as biofertilizers. International Journal of Agronomy, 2019 , 1-7. https://doi.org/10.1155/2019/4917256

Kang, S. M., Joo, G. J., Hamayun, M., Na, C. I., Shin, D. H., Kim, H. Y., Hong, J. K. \& Lee, I. J. (2009). Gibberellin production and phosphate solubilization by newly isolated strain of Acinetobacter calcoaceticus and its effect on plant growth. Biotechnology Letters, 31(2), 277-281. https://doi.org/10.1007/s10529008-9867-2

Khan, A. A., Jilani, G., Akhtar, M. S., Naqvi, S. M. S. \& Rasheed, M. (2009). Phosphorus solubilizing bacteria: occurrence, mechanisms and their role in crop production. Journal of Agricultural and Biological, Sciences 1(1):48-58.

Kucey, R. M. N., Janzen, H. H. \& Leggett, M. E. (1989). Microbially mediated increases in plant-available phosphorus. Advances in Agronomy, 42, 199-228. https://doi.org/10.1016/s0065-2113(08)60525-8

Kumar, A. (2016). Phosphate solubilizing bacteria in agriculture biotechnology: diversity, mechanism and their role in plant growth and crop yield. International Journal of Advanced Research, 4(5), 116-124. https://doi.org/10.21474/ijar01/111 
Lara, N., Figueroa, L., Carvajal, F., Zapata, Y., Urbina, C. \& Escobar, H. (2013). Quantitative differentiation between soil organic carbon and biochar carbon in Aridisol. International Journal of Agriculture and Natural Resources, 40(2), 387-395. https://doi.org/10.4067/s0718-16202013000200013

Lee, K-E., Adhikari, A., Kang, S-M., You, Y-H., Joo, G-J., Kim, J-H., Kim, S-J. \& Lee, I-J. (2019). Isolation and Characterization of the High Silicate and Phosphate Solubilizing Novel Strain Enterobacter ludwigii GAK2 that Promotes Growth in Rice Plants. Agronomy 9(3), 144-155. https://doi.org/10.3390/agronomy9030144

Lehmann, J., \& Joseph, S. (2009). Biochar for environmental management: science and technology. Earthscan, 1, 1-12.

Li, H., Dong, X., da Silva, E. B., de Oliveira, L. M., Chen, Y. \& Ma, L. Q. (2017). Mechanisms of metal sorption by biochars: biochar characteristics and modifications. Chemosphere, 178:466-478. https://doi.org/10.1016/j.chemosphere.2017.03.072

Li, S., Wang, S., Fan, M., Wu, Y. \& Shangguan, Z. (2020). Interactions between biochar and nitrogen impact soil carbon mineralization and the microbial community. Soil and Tillage Research, 196, 104437. https://doi.org/10.1016/j.still.2019.104437

Liang, X., Jin, Y., He, M., Liu, Y., Hua, G., Wang, S. \& Tian, G. (2017). Composition of phosphorus species and phosphatase activities in a paddy soil treated with manure at varying rates. Agriculture, Ecosystems \& Environment, 237, 173-180. https://doi.org/10.1016/j.agee.2016.12.033

Liffourrena, A. S. \& Lucchesi, G. I. (2018). Alginate-perlite encapsulated Pseudomonas putida A (ATCC 12633) cells: Preparation, characterization and potential use as plant inoculants. Journal of Biotechnology, 278, 28-33. https://doi.org/10.1016/j.jbiotec.2018.04.019

Lima, J. R. de S., de Moraes Silva, W., de Medeiros, E. V., Duda, G. P., Corrêa, M. M., Martins Filho, A. P., Clermont-Dauphin, C., Dantas, A. C. \& Hammecker, C. (2018) Effect of biochar on physicochemical properties of a sandy soil and maize growth in a greenhouse experiment. Geoderma, 319, 14-23. https://doi.org/10.1016/j.geoderma.2017.12.033

Malusà, E., Pinzari, F. \& Canfora, L. (2016). Efficacy of biofertilizers: challenges to improve crop production. Microbial Inoculants in Sustainable Agricultural Productivity, 17-40. https://doi.org/10.1007/978-81-322-2644-4_2

Manzoor, M., Abbasi, M. K. \& Sultan, T. (2017) Isolation of phosphate solubilizing bacteria from maize rhizosphere and their potential for rock phosphate solubilization-mineralization and plant growth promotion. Geomicrobiology Journal, 34(1), 81-95. ttps://doi.org/10.1080/01490451.2016.1146373

Martinez, C. L. M., Jesus, M. S., Vakkilainen, E., Cardoso, M. \& Almeida, G. M. (2019). Bioenergy Technology Solutions in Brazil. Brazilian Journal of Wood Science, 10(2), 112-122. https://doi.org/10.12953/2177-6830/rcm.v10n2p112-122

Martins Filho, A. P., de Medeiros, E. V., de Sousa Lima, J. R., Duda, G. P., de Moraes Silva, W., Antonino, A. C. D. \& da Silva, J. S. A. (2020). Impact of coffee biochar on soil carbon, microbial biomass and enzymatic activities in Semiarid Sandy soil cultivated with maize. Revista Brasileira de Geografia Física, 13(02), 903-914. https://doi.org/10.26848/rbgf.v13.3.p903-914

Massenssini, A. M., Tótola, M. R., Borges, A. C. \& Costa, M. D. (2015). Potential Phosphate Solubilization Mediated by Rhizospheric Microbiota of Eucalyptus Cultivated in a Typical Toposequence of the Zona da Mata, Minas Gerais. Revista Brasileira de Ciência do Solo, 39(3), 692-700. https://doi.org/10.18178/ijesd.2017.8.5.979

Medeiros, E. V., dos Santos, M. D. C. H., da Costa, D. P., Duda, G. P., de Oliveira, J. B., da Silva, J. A., Lima, J. R. S. \& Hammecker, C. (2020). Effect of biochar and inoculation with Trichoderma aureoviride on melon growth and sandy Entisol quality. Australian Journal of Crop Science, 14(6), 971-977. https://doi.org/10.21475/ajcs.20.14.06.p2302

Medeiros, E. V., Moraes, M. C., Costa, D. P., Silva, J. S., Oliveira, J. B., Lima, J. R. S., Menezes, R. S. C. \& Hammecker, C. (2020). Biochar and Trichoderma aureoviride applied to the sandy soil: effect on soil quality and watermelon growth. Notulae Botanicae Horti Agrobotanici Cluj-Napoca, 48(2), 735-751. https://doi.org/10.15835/nbha48211851

Medeiros, E. V., Silva, A. O., Duda, G. P., dos Santos, U. J. \& de Souza Junior, A. J. (2019). The combination of Arachis pintoi green manure and natural phosphate improves maize growth, soil microbial community structure and enzymatic activities. Plant and Soil, 435(1), 175-185. https://doi.org/10.1007/s11104-018-3887-z

Mendes, I. D. C. \& dos Reis Junior, F. B. (2003). Microrganismos e disponibilidade de fósforo (P) nos solos: uma análise crítica. Embrapa Cerrados, Documentos, Planaltina Brasil.

Mohamed, H. M. \& Almaroai, Y. A. (2017). Effect of phosphate solubilizing bacteria on the uptake of heavy metals by corn plants in a long-term sewage wastewater treated soil. International Journal of Environmental Science and Development, 8(5), 366. https://doi.org/10.18178/ijesd.2017.8.5.979

Nadeem, S. M., Zahir, Z. A., Naveed, M. \& Nawaz, S. (2013). Mitigation of salinity-induced negative impact on the growth and yield of wheat by plant growthpromoting rhizobacteria in naturally saline conditions. Annals of Microbiology, 63(1), 225-232. https://doi.org/10.1007/s13213-012-0465-0

Nakbanpote, W., Panitlurtumpai, N., Sangdee, A., Sakulpone, N., Sirisom, P. \& Pimthong, A. (2014). Salt-tolerant and plant growth-promoting bacteria isolated from $\mathrm{Zn} / \mathrm{Cd}$ contaminated soil: identification and effect on rice under saline conditions. Journal of Plant Interactions, 9(1), 379-387. https://doi.org/10.1080/17429145.2013.842000

Nobile, C. M., Bravin, M. N., Becquer, T. \& Paillat, J. M. (2020). Phosphorus sorption and availability in an andosol after a decade of organic or mineral fertilizer applications: Importance of $\mathrm{pH}$ and organic carbon modifications in soil as compared to phosphorus accumulation. Chemosphere, 239, 124709. https://doi.org/10.1016/j.chemosphere.2019.124709

Ogut, M., Er, F. \& Kandemir, N. (2010). Phosphate solubilization potentials of soil Acinetobacter strains. Biology and Fertility of Soils, 46(7), 707-715. https://doi.org/10.1007/s00374-010-0475-7

Okon, Y. \& Labandera-Gonzalez, C. A. (1994). Agronomic applications of Azospirillum: an evaluation of 20 years worldwide field inoculation. Soil Biology \& Biochemistry, 26(12), 1591-1601. https://doi.org/10.1016/0038-0717(94)90311-5 
Olivares, F. L., Baldani, V. L., Reis, V. M., Baldani, J. I. \& Döbereiner, J. (1996). Occurrence of the endophytic diazotrophs Herbaspirillum spp. in roots, stems, and leaves, predominantly of Gramineae. Biology and Fertility of Soils, 21(3), 197-200. https://doi.org/10.1007/s003740050049

Oliveira Filho, J. S., Ferrari, A. C., Pereira, M. G., Pinto, L. A. D. S. R., Zonta, E. \& Matos, T. S. (2020). Phosphorus accumulation in soil after successive applications of swine manure: a long-term study in Brazil. Environmental Earth Sciences, 79(2), 62. https://doi.org/10.1007/s12665-019-8805-z

Owen, D., Williams, A. P., Griffith, G. W. \& Withers, P. J. (2015). Use of commercial bio-inoculants to increase agricultural production through improved phosphrous acquisition. Applied Soil Ecology, 86, 41-54. https://doi.org/10.1016/j.apsoil.2014.09.012

Paiva, C. A. O., Marriel, I. E., Gomes, E. A., Cota, L. V., dos Santos, F. C., Tinoco, S. M. S., Lana, U. G. P., Oliveira, M. C., Mattos, B. B., Alves, V. M. C., Ribeiro, V. P. \& Vasco Junior, R. (2020). Recomendação agronômica de cepas de Bacillus subtilis e Bacillus megaterium na cultura do milho. Embrapa Milho e Sorgo, Circular Técnica.

Palansooriya, K. N., Wong, J. T. F., Hashimoto, Y., Huang, L., Rinklebe, J., Chang, S. X., Bolan, N., Wang, H. \& Ok, Y. S. (2019). Response of microbial communities to biochar-amended soils: a critical review. Biochar 1(1), 3-22. https://doi.org/10.1007/s42773-019-00009-2

Pandey, D., Daverey, A. \& Arunachalam, K. (2020). Biochar: Production, properties and emerging role as a support for enzyme immobilization. Journal of Cleaner Production, 255, 120267. https://doi.org/10.1016/j.jclepro.2020.120267

Perin, L., Martínez-Aguilar, L., Paredes-Valdez, G., Baldani, J. I., Estrada-De Los Santos, P., Reis, V. M., Caballero-Mellado, J. (2006). Burkholderia silvatlantica sp. nov., a diazotrophic bacterium associated with sugar cane and maize. International Journal of Systematic and Evolutionary Microbiology, 56(8), 1931-1937. https://doi.org/10.1099/ijs.0.64362-0

Pikovskaya, R. I. (1948). Mobilization of phosphorus in soil in connection with vital activity of some microbial species. Mikrobiologiya, 17, 362-370.

Posso, E. J. S. \& de Prager, M. S. (2017). Production of organic acids by rhizosphere microorganisms isolated from a Typic Melanudands and its effects on the inorganic phosphates solubilization. Acta Agronómica, 66(2), 1-23.

Prabhu, N., Borkar, S. \& Garg, S. (2018). Phosphate solubilization mechanisms in alkaliphilic bacterium Bacillus marisflavi FA7. Current Science, 114(4), 845853. https://doi.org/10.18520/cs/v114/i04/845-853

Prabhu, N., Borkar, S. \& Garg, S. (2019). Phosphate solubilization by microorganisms: overview, mechanisms, applications and advances. Advances in Biological Science Research, 161-176. https://doi.org/10.1016/B978-0-12-817497-5.00011-2

Qian, L., Chen, Y., Ouyang, D., Zhang, W., Han, L., Yan, J., Kvapil, P. \& Chen, M. (2020). Field demonstration of enhanced removal of chlorinated solvents in groundwater using biochar-supported nanoscale zero-valent iron. Science of the Total Environment, 698, 134215. https://doi.org/10.1016/j.scitotenv.2019.134215

Razzaghi, F., Obour, P. B. \& Arthur, E. (2020). Does biochar improve soil water retention? A systematic review and meta-analysis. Geoderma, $361,114055$. https://doi.org/10.1016/j.geoderma.2019.114055

Reis, M., Olivares, F. L. \& Döbereiner, J. (1994). Improved methodology for isolation of Acetobacter diazotrophicus and confirmation of its endophytic habitat. World Journal of Microbiology \& Biotechnology, 10(4), 401-405. https://doi.org/10.1007/bf00144460

Reetha, S., Bhuvaneswari, G., Thamizhiniyan, P. \& Mycin, T. R. (2014). Isolation of indole acetic acid (IAA) producing rhizobacteria of Pseudomonas fluorescens and Bacillus subtilis and enhance growth of onion (Allim cepa L.). International Journal of Current Microbiology and Applied Sciences, 3(2), 568574.

Santos, D. R. D., Gatiboni, L. C. \& Kaminski, J. (2008). Factors affecting the phosphorus availability and the fertilization management in no-tillage system. Ciência Rural, 38(2), 576-586.

Satyaprakash, M., Nikitha, T., Reddi, E. U. B., Sadhana, B. \& Vani, S. S. (2017). Phosphorous and phosphate solubilising bacteria and their role in plant nutrition. International Journal of Current Microbiology and Applied Sciences, 6(4), 2133-2144. https://doi.org/10.20546/ijcmas.2017.604.251

Schmalenberger, A. \& Fox, A. (2016). Bacterial mobilization of nutrients from biochar-amended soils. In: Gadd GM, Sariaslani S (Eds.), Advances in Applied Microbiology, Academic Press, pp 109-159. https://doi.org/10.1016/bs.aambs.2015.10.001

Shahzad, S., Khan, M. Y., Zahir, Z. A., Asghar, H. N. \& Chaudhry, U. K. (2017). Comparative effectiveness of different carriers to improve the efficacy of bacterial consortium for enhancing wheat production under salt affected field conditions. Pakistan Journal of Botany, 49(4), 1523-1530.

Shi, W., Ju, Y., Bian, R., Li, L., Joseph, S., Mitchell, D. R., Munroe, P., Taherymoosavi, S. \& Pan, G. (2020). Biochar bound urea boosts plant growth and reduces nitrogen leaching. Science of the Total Environment, 701, 134424. https://doi.org/10.1016/j.scitotenv.2019.134424

Silva, M. F. D., Oliveira, P. J. D., Xavier, G. R., Rumjanek, N. G. \& Reis, V. M. (2009). Inoculants containing polymers and endophytic bacteria for the sugarcane crop. Pesquisa Agropecuária Brasileira, 44(11), 1437-1443.

Silva, M. F., de Souza Antônio, C., de Oliveira, P. J., Xavier, G. R., Rumjanek, N. G,, de Barros Soares, L. H. \& Reis, V. M. (2012). Survival of endophytic bacteria in polymer-based inoculants and efficiency of their application to sugarcane. Plant and Soil, 356(1-2), 231-243. https://doi.org/10.1007/s11104-012$1242-3$

Singleton, P., Keyser, H. \& Sande, E. (2002). Development and evaluation of liquid inoculants. Inoculants and nitrogen fixation of legumes in Vietnam. ACIAR Proceedings 109e, Canberra 52-66.

Sivakumar, P. K., Parthasarthi, R. \& Lakshmipriya, V. P. (2014). Encapsulation of plant growth promoting inoculant in bacterial alginate beads enriched with humic acid. International Journal of Current Microbiology and Applied Sciences, 3(6), 415-422. 
Research, Society and Development, v. 11, n. 1, e36211124885, 2022

(CC BY 4.0) | ISSN 2525-3409 | DOI: http://dx.doi.org/10.33448/rsd-v11i1.24885

Smith, R. S. (1992). Legume inoculant formulation and application. Canadian Journal of Microbiology, 38(6), 485-492. https://doi.org/10.1139/m92-080

Sousa, G. G., Thales, V. D. A., Braga, E. S., de Azevedo, B. M., Marinho, A. B. \& Borges, F. R. (2013). Fertigation with bovine biofertilizer: Effects on growth, gas exchang and yield of physic nut (Jatropha curcas). Revista Brasileira de Ciências Agrárias, 8(3), 503-509.

Stephens, J. H. G. \& Rask, H. M. (2000). Inoculant production and formulation. Field Crops Research, 65(2-3), 249-258. https://doi.org/10.1016/s03784290(99)00090-8

Szilagyi-Zecchin, V. J., Mógor, Á. F., Ruaro, L. \& Röder, C. (2015). Tomato seedlings growth (Solanum lycopersicum) promoted by bacteria Bacillus amyloliquefaciens subsp. Plantarum FZB42 in organic system. Revista de Ciências Agrárias, 38(1), 26-33.

Teng, Z., Shao, W., Zhang, K., Huo, Y. \& Li, M. (2019). Characterization of phosphate solubilizing bacteria isolated from heavy metal contaminated soils and their potential for lead immobilization. Journal of Environmental Management, 231, 189-197. https://doi.org/10.1016/j.jenvman.2018.10.012

Vance, C. P., Uhde-Stone, C. \& Allan, D. L. (2003). Phosphorus acquisition and use: critical adaptations by plants for securing a nonrenewable resource. New Phytologist, 157(3), 423-447. https://doi.org/10.1046/j.1469-8137.2003.00695.x

Vassilev, N., Eichler-Löbermann, B. \& Vassileva, M. (2012). Stress-tolerant P-solubilizing microorganisms. Applied Microbiology and Biotechnology, 95(4), 851-859. https://doi.org/10.1007/s00253-012-4224-8

Walpola, B. C. \& Yoon, M. H. (2012). Prospectus of phosphate solubilizing microorganisms and phosphorus availability in agricultural soils: A review. African Journal of Microbiology Research, 6(37), 6600-6605. https://doi.org/10.5897/ajmr12.889

Wang, J., Xiong, Z. \& Kuzyakov, Y. (2016). Biochar stability in soil: meta-analysis of decomposition and priming effects. Gcb-Bioenergy, 8(3), 512-523. https://doi.org/10.1111/gcbb.12266

Withers, P. J., Rodrigues, M., Soltangheisi, A., De Carvalho, T. S., Guilherme, L. R., Benites, V. D. M., Gatiboni, L. C., de Sousa, D. M. G., Nunes, R. S., Rosolem, C. A., Andreote, F. D., Oliveira Jr, A., Coutinho, E. L. M. \& Pavinato, P. S. (2018). Transitions to sustainable management of phosphorus in Brazilian agriculture. Scientific Reports, 8(1), 1-13. https://doi.org/10.1038/s41598-018-20887-z

Yan, Y., Sarkar, B., Zhou, L., Zhang, L., Li, Q., Yang, J. \& Bolan, N. (2020). Phosphorus-rich biochar produced through bean-worm skin waste pyrolysis enhances the adsorption of aqueous lead. Environmental Pollution, 266, 115177. https://doi.org/10.1016/j.envpol.2020.115177

Ye, S., Zeng, G., Tan, X., Wu, H., Liang, J., Song, B., Tanga, N., Zhanga, P., Yanga, Y., Chena, Q. \& Li, X. (2020). Nitrogen-doped biochar fiber with graphitization from Boehmeria nivea for promoted peroxymonosulfate activation and non-radical degradation pathways with enhancing electron transfer. Applied Catalysis B: Environmental, 269, 118850. https://doi.org/10.1016/j.apcatb.2020.118850

Zhu, J., Li, M. \& Whelan, M. (2018). Phosphorus activators contribute to legacy phosphorus availability in agricultural soils: a review. Science of the Total Environment, 612, 522-537. https://doi.org/10.1016/j.scitotenv.2017.08.095

Zuffo, A. M., Bruzi, A. T., de Rezende, P. M., de Carvalho, M. L. M., Zambiazzi, E. V., Soares, I. O. \& Silva, K. B. (2016). Foliar application of Azospirillum brasilense in soybean and seed physiological quality. African Journal of Microbiology Research, 10(20), 675-680. https://doi.org/10.5897/ajmr2016.7911 